Agriculture and Rural Development

Department

The World Bank

January 1992

WPS 836

\title{
Sources \\ of Income Inequality in Rural Pakistan
}

\section{A Decomposition Analysis}

\author{
Richard H. Adams, Jr. \\ and \\ Harold Alderman
}

That some people own more land than others is not the main source of agricultural income inequality in rural Pakistan. That some people receive higher profits and returns to labor on their cultivation than do others is. Reducing inequality might require providing more training in managerial and technical skills. 


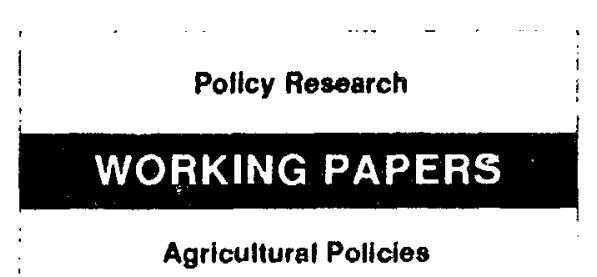

WPS 836

This paper - a product of the Agricultural Policies Division, Agriculture and Rural Development Department -... is part of a larger effort in the Department to monitor the impact of agricultural policies on poverty. Copies of this paper are available free from the World Bank, $1818 \mathrm{H}$ Street NW, Washington DC 20433. Please contact Ciccly Spooner, room N8-039, extension 30464 (34 pages). January 1992.

Using panel data from a three-ycar study of 727 households, Adams and Alderman identify the sources of income inequality in rusal Pakistan.

First, they decompose total rural income among five sources: agricultural, livestock, rental, nonfarm, and transfer income. This decomposition shows that agricultural income contributes most to incquality in total rural income.

Next, they decompose the sources of inequality in agricultural income. This leads to the surprising finding that incquitable ownership of land is not the main source of inequality in agricultural income. Income from returns to labor and crop profits contribute most to this area of inequality.

One way to reduce rural income inequality might be to find more ways to narrow the disparitics between abilities, perhaps by leaching more managerial and technical skills to agriculturists.

According to Adams and Alderman, policy....akers concemed about inequality in rural Pakistan would also be well advised to pay more attention to livestock. Income from livestock apparently decreases the inequalitics in income.

The Policy Research Working Paper. Series disseminates the findings of work under way in the Bank. An objective of the series \& to get these findings out quickly, even if presentations are less than fully polished The findungs, interpretations, and conclusions in these papers do not necessarily represent official Bank policy. 
Sources of Income Inequality in Rural Pakistan:

A Decomposition Analysis

by

Richard H. Adams. Jr.

International Food Policy Research Institute

and

Harold Alderman

World Bank (AGRAP)

Table of Contents

1. The Decomposition of Income Inequality 3

$\begin{array}{lll}2 . & \text { Data Set } & 7\end{array}$

3. Income Inequality in Rural Pakistan, 1986-89 9

4. Sources of Agricultural Income Inequality in Rural Pakistan 13

$\begin{array}{ll}\text { 5. Conclusion } & 17\end{array}$

$\begin{array}{ll}\text { Notes } & 20\end{array}$

$\begin{array}{lr}\text { References } & 23\end{array}$

$\begin{array}{lr}\text { Tables } & 26\end{array}$ 
Ever since the appearance of Kuznets' seminal works (1955, 1963) on the relationship between economic development and income inequality, there has been much interest and speculation about the sources of income inequality in the developing world. Within the past fifteen years the development of new methodologies for decomposing the sources of income inequality has infused this subject area with new data and insights. Using various techniques, a number of empiricai studies in individual developing countries have pinpointed the contribution of different sources of income to total income inequality. ${ }^{1}$ These studies have decomposed income inequality by economic sector (e.g., urban vs, rural), income source (e.g., income from labor vs. capital vs. land) and family characteristics (i.cluding educational and occupational attributes of workers).

Such empirical studies are of considerable potential use to developing country policymakers because they help identify both the structure of income inequality and how the character of that inequality changes over time. Equipped with such information, government officials can devise specific policy measures to help improve the distribution of urban and rural incomes.

This paper seeks to add to our knowledge about the sources of income inequality in the developing world by examining the sources of such inequality in rural Pakistan. The paper seeks to make two contributions. First, it uses panel data gathered in a rural area to identify the contribution of different sources of income -. 
agricultural, livestock, rental, non-farm and transfer -- to total rural income inequality. This is useful because, to date, few decomposition studies have used time-series data in ungrouped (disaggregated) form to show how the contribution of various income sources to rural inequality in a developing country fluctuates over time. $^{2}$ Second, after identifying agricultural income as the main source of rural income inequality, this study decomposes the sources of agricultural income with a view to understanding how much of this agricultural inequality is due to unequal landownership. Rather surprisingly, this analysis shows that while landownership is highly skewed in rural Pakistan, unequal landownership does not represent the main source of agricultural income inequality in rural Pakistan. According to this study, the main source of agricultural inequality is income from returns to labor and crop profit.

The paper proceeds in five sections. Section 1 examines the measurement of income inequality and presents the decomposition of several inequality measures. Section 2 presents the data set from rural Pakistan. iection 3 then analyzes changes in the sources of income inequality rural Pakistan over three years, 1986-1989. In this section agricultural income is identified as the leading source of income inequality in rural Pakistan. Section 4 therefore decomposes the sources of agricultural income inequality. Section 5 presents the conclusions of the study. 


\section{The Decomposition of Iricome inequalitiy}

At the start of any decomposition exercise, the question arises: what ineasure of inequality should be chosen for the analysis? A number of different inequality measures have been proposed in the literature (Fields, 1980; Kakwani, 1980). Following Foster (1985) and others, the chosen measure should have five basic properties. They are: (1) Pigou-Dalton transfer sensitivity; (2) symmetry; (3) mean independence; (4) population homogeneity; (5) decomposability. Pigou-Dalton transfer sensitivity holds if the measure of inequality increases whenever income is transferred from one person to someone richer. Symmetry holds if the measure of inequality remains unchanged when individuals switch places in the income order. Mean independence holds if a proportionate change in all incomes leaves the measure of inequality unchanged. Population homogeneity holds if increasing (or decreasing) the population size across all income levels has no effect on the measured level of inequality.

Decomposability, for the purposes of this analysis, refers to source decomposability. Ideally, one would expect that an inequality measure is source decomposable if total inequality can be broken down into a weighted sum of inequality by various income sources (e.g. agricultural and non-agricultural income). However, this is not possible if there is covariance among the sources of income. Thus, no inequality measure is source decomposable if it cannot deal with covariance among the income sources.

There are several measures of inequality which meet these five properties. These measures include Theil's entropy index T, Theil's second measure $L$, the coefficient of variation and the Gini 
coefficient. ${ }^{3}$ However, while the two Theil measures meet all the desirable properties, they are not decomposable when sources of income are overlapping and not disjoint. Since the houservids in this study typically receive income from several different sources, the two Theil measures cannot be used.

Shorrocks (1982) has shown that the results of decomposing any inequality measure depend on the rule used in the decomposition procedure. In the absence of any restrictions, for ariy inequality measure the inequality of total income can be allocated in many ways between the components of total income (Shorrocks, 1982: 199). For this reasor, it seems best to base the decomposition analysis on the two remaining inequality measures: the coefficient of variation and the Gini coefficient. 41 though these two inequality measures are decomposable for any number of income sources, this study will divide income into five sources: agricultural, livestock, rental, non-farm and transfer. Unlike other decomposition studies which are based on a more limited number of income sources (e.g. Glewwe, 1986), such a division provides more detail for understanding the various components of income inequality.

The source decomposition based on the coefficient of variation can be developed following Shorrocks (1982) and Ercelawn (1984). Let total income, $y$, consist of income from $k$ sources. The varian $\geq$ of total income, $\sigma^{2}$, can be written as the sum of variances of each source of income, $\sigma^{2}$, and of the covariances between sources of income, $\sigma_{i j}$ :

$$
\sigma^{2}=\Sigma \sigma^{2}+\sum_{i \neq j} \sigma_{1 j}
$$


The contribution of the $i$-in source of income to total income variance consists of the $i$-th income variance and the part of the covariances allocated to the $i$-th source. According to Shorrocks (1982), the "natural" decomposition of the variance assigns to the $i$ th source exactly one-half of all covariances involving the $i-t h$ income source. This leads to the expression:

$$
\sigma^{2}=\Sigma \sigma_{i y}
$$

where the (absolute) contribution of the $i$-th source is measured by its covariance with total income, $y$. This relationship can be rewritten so as to express the contribution in relative terms. As is apparent, the relative contributions remain the same whether inequality is measured by the variance or by the coefficient of variation. Since the variance does not meet the axiom of mean independence (i.e. it is not invariant to proportional changes in all incomes) the coefficient of variation will be adopted here. The decomposition corresponding to the coefficient of variation can be further elucidated by defining the following terms:

$$
\sum w_{i} c_{i}=1 ; w_{i}=\frac{\mu_{i}}{\mu} ; c_{i}=p_{i} \frac{\sigma / / \mu_{i}}{\sigma / \mu}
$$

where $w_{i} c_{i}$ is the so-called "factor inequality weight" of the $i-t h$ source in overall inequality; $\mu_{i}$ and $\mu$ are the mean income from the $i$ th source and from all sources, respectively; $c_{i}$ is the relative concentration coefficient of the $i$-th source in overall inequality; 
and $\rho_{i}$ is the correlation coefficient between the $i$-th jource and total income.

The cecomposition of the Gini coefficiert can be developed as follows. Pyatt et a1. (1980) have shown that the Gini coefficient of total income, $G$, cari be written as:

$$
G=\frac{2}{n \mu} \operatorname{Cov}(y, r)
$$

where $n$ is the number of observations, $y$ refers to the series of total incomes and $r$ refers to the series of corresponding ranks. On this basis the Gini coefficient of the $i$-th source of income, $G_{i}$, can be expressed as:

$$
G_{i}=\frac{2}{n \mu_{i}} \operatorname{Cov}\left(y_{i}, r_{i}\right)
$$

where $y_{i}$ and $r_{i}$ refers to the series of incomes from the $i$-th source and corresponding ranks, respectively. Since total income is the sum of source incomes, the covariance between total income and its rank can be written as the sum of covariances between each source income and rank of total income. Equations (4) and (5) can then be used to express the total income Gini as a function of the source Ginis:

$$
G=\Sigma-\frac{\mu_{i}}{\mu} R_{i} G_{i}
$$

where $R$ is the "correlation ratio" expressed as:

$$
R_{1}=\frac{\operatorname{cov}\left(y_{i}, r\right)}{\operatorname{cov}\left(y_{i}, r_{i}\right)}=\frac{\begin{array}{c}
\text { covariance between source } \\
\text { income amount and total income rank }
\end{array}}{\begin{array}{c}
\text { covariance between source } \\
\text { income amolint and source income rank }
\end{array}}
$$

The decomposition corresponding to the Gini coefficient can then be expressed by defining the following terms: 


$$
\Sigma w_{i} g_{i}=1 ; w_{i}=\frac{H_{i}}{\mu} ; g_{i}=R_{i} \frac{G_{i}}{G}
$$

where $w_{i} g_{i}$ is the "factor inequality weight" of the $i$-th source in overall inequality; and $g_{i}$ is the relative concentration coefficient of the $i$-th source in overall inequality.

As noted by Lerman and Yitzhaki (1985), the Gini correlation ratio ( $R$ ) in equation (7) has properties similar to the Pearson correlation. Sike Pearson's, the Gini correlation ranges between -1 and +1 . R will equal $1(-1)$ when an income source is an increasing (decreasing) function of total income. When the income source is a constant, then $R$ will equal 0 , implying that the source's share of the Gini is 0 .

\section{Data Set}

Data come from a three-year survey of 734 ho' eholds in three provinces in rural Pakistan. ${ }^{4}$ Since the goal of this survey was to analyze the determinants of rural poverty, the survey was not designed to be representative of the rural population as a whole in Pakistan. In each province the poorest district was selected on the basis of a production and infrastructure index elaborated by Pasha and Hasar. (1982). The selected districts included Attock (Punjab province), Badin (Sind province) and Dir (Northwest Frontier province). Since rural poverty also exists in relatively prosperous areas, a fourth district Faisalabad (Punjab province) was added to the survey. ${ }^{5}$

Surveying of the households continued over a three-year perird, 1986-87, 1987-88 and 1988-89. Of the total 734 households, 7 
$-8-$

households were excluded because of missing or incomplete data. The analysis is therefore based on data from 72.7 households. ${ }^{6}$

As noted above, total income for each household was divided into five sources:

(1) Agricultural - Includes net income in agriculture plus return to own agricultural labor;

(2) Non-farm - Includes non-farm wage earnings and profits from non-farm enterprises;

(3) Livestock - Includes net returns from livestock (cattle, poultry);

(4) Rental income - Includes rents received from ownership of assets (1 and, machinery, water)

(5) Iransfer - Includes remittances from abroad, internal remittances, pensions (government) and zakat (payments to poor).

Table 1 presents summary data for the five income sources over the three survey years. The data show that non-farm income represents the most important source of mean per capita household income in all three years. Agricultural income represents the second most important source of income. The importance of the other three income sources -transfer, livestock and rental -- varies by year.

As calculated from Table 1, the Gini coefficient of inequality of per capita household income for the sample increased slightly over the period of : e survey: from 0.384 in 1986-87 to 0.408 in 1987-88 to 0.417 in 1988-89. These Gini coefficients suggest that the distribution of income in the rural survev sites is roughly similar to that recorded for other Asian countries.' 
In Table 2 the five sources of income are presented by income quintile group. The results underscore those of other studies ${ }^{8}$ in pinpointing the importance or non-farm income for poor households. According to the data, households in the lowest income quintile group receive over 40 percerit of their mean per capita income from non-farm activities. The second most important source of income for poor households is livestock income. By means of contrast, households in the highest income quintile receive the bulk of their mean per capita income from agricultural and rental income.

\section{Income Inequality in Rural Pakistan, 1986-1989}

Decomposing the coefficient of yariation and the Gini coefficient provides two ways for measuring the contribution of any income source to overall income inequality. First, it can be asked whether inequality in an income source serves to increase or decrease overail income inequality. Second, it is possible to identify how much of the overall inequality is due to any particular income source.

An income source can be defined as inequality-increasing or inequality-decreasing on the basis of whether or not an enla ged share of that income source leads to an increase or decrease in overall inconie inequality. From the decomposition equations (3) and (8), it follows that the $j-$ th income source is inequality-increasing or inequality-decreasing according to whether $c_{i}\left(\right.$ or $\left.g_{i}\right)$ is greater than or less than unity. ${ }^{9}$

Table 3 reports the decomposition results with respect to the distinction between inequality-increasing versus inequality-decreasing 
for tho five sources of income: (1) agricultural; (2) livestock: (3) rental; (4) non-farm; and (5) transfer.

In Table 3 both decompositions agree that for all three years two income sources - agricultural and rental .- represent inequalityincreasing sources of income. Similarly, both secompositions agree that for all three years one source of income -- non-farm -represents an inequality-decreasing source of income. However, for two income sources - transfer and livestock - the alternative decompositions give different results for various years. ${ }^{10}$ For two of three years both decompositions agree that transfer income represents an inequality-increasing source of income; but for one of the years the coefficient of variation suggests the opposite. Similarly, for two of the three years both decompositions agree that livestock income is an inequality-decreasing source of income; but for one of the years the coefficient of variation suggests the opposite.

Table 4 presents the decomposition results for relative factor inequality weights of source incomes in overall income inequality. Four items deserve mention here. First, all of the Gini decompositions and two of the three coefficient of variation decompositions agree that agricultural income makes the largest contribution to overall inequality. Depending on the year, the two decompositions suggest that agricultural income accounts for between 26.9 and 42.2 percent of overall inequality. Second, all of the Gini decompositions and two of the three coefficient of variation decompositions agree that livestock income makes the smallest contribution to overall inequality. Depending on the year, the two decompositions suggest that livestock income accounts for between 0.2 
and 16.2 percent of overall income inequality. Third, the results of Table 4 suggest that the contributions of other income sources to overall inequality vary widely depending on the index used to measure inequality. Consider, for example, the contribution of transfer income. In one single year (1986-87) the contribution of transfer income to overall inequality varies from 22.6 percent (using the Gini decomposition) to 28.5 percent (using the coefficient of variation decomposition). These results tend to corroborate Shorrocks' finding (1983) that fa-tor inequality weights for any income source can vary widely depending on the index used to decompose inequality. Fourth, the results of Table 4 show appreciable changes in the contributions of various income sources to overall inequality between years. For example, as measured by the Gini coefficient the contribution of rental income to overall inequality increases by 27.4 percent between 1987-88 and 1988-89. Using the same index, between 1987-88 and 198889 the contribution of transfer income to overall inequality declines by 102 percent.

The results of Table 4 can be further explained by analyzing the results of the Gini decomposition. This is done in Table 5, which presents the three elements of the Gini decomposition procedure: source income weight; (2) source gini; and (3) correlation ratio between source income and total income inequality.

Row (1) of Table 5 shows that non-farm income constitutes the most important source of income for all three years, accounting for between 29.8 and 32.8 percent of all income. Agricultural income represents the second most important source of income for all three years, accounting for between 29.8 and 31.6 percent of all income. 
The importance of the other sources of income varies by year, with rental income representing the least important source of income for two of the three years.

Row (2) of Table 5 shows that rental income has the highest source gini for all three years and is thus the least equally distributed income source. This is a reflection of the fact that -. depending on the year .. only 29.8 to 34.3 percent of all 727 households receive rental income. By means of contrast, row (2) shows that non-farm income has the lowest source gini for two of three years and thus represents the most equally distributed source of income. Depending on the year between 74.4 and 76.7 percent of all 727 households receive non-farm income.

Row (3) of Table 5 reports the correlation ratios between source income and total income inequality. The figures show that inequality in rental income is highly correlated with overall income inequality. By comparison, the data show that inequality in non-farm and livestock income have a low degree of correlation with total income inequality.

The data in Table 5 serve to explain the factor inequality weights reported in the preceding table. For example, Table 4 shows that agricultural income has the highest factor inequality weight and makes the largest contribution to overall income inequality. This is because agricultural income has a large share of total income, a middle-sized source gini and is moderately correlated with overall income inequality. At the other extreme, Table 4 shows that livestock income makes the smailest contribution to overall income inequality. This is because livestock income iras a middle-sized share 
of total income, a low source gini and is poorly correlated with overall income inequality.

\section{Sources of Agricultural Income Inequal ity in Rural Pakistan}

The fact that agricultural income makes the largest contribution to overall income inequality makes it useful to decompose the sources of agricultural income inequality. Such an exercise is instructive because it can pinpoint the proportion of agricultural income inequality that comes from unequal landownership. In rural Pakistan land is distributed quite unevenly: in the survey sites the Gini coefficients of landownership and landholdings are 0.769 and 0.630 , respectively. ${ }^{11}$ In the past, a number of studies have suggested that such unequal land distribution represents a major determinant of rural income inequality in Pakistan and other developing countries. ${ }^{12}$

Two problens must be addressed before agricultural inequality can be decomposed in this study. First, in order to include all agricultural income in the decomposition procedure, the income categories used in this study must be revised. Most importantly, the income received from 1 and rent that has heretofore been classified as part of "rental income" needs to be reclassified as part of "agricultural income." Under reasonable assumptions, owner cultivation using hired labor and tenancy will have similar levels of production and profits. However, if "rental income" is not reclassified as part of "agricultural income," these two alternative uses would have very different implications for income distribution in agriculture. Second, it is useful to distinguish the rent notionally paid by the landowning household to itself from returns to labor and 
crop profit. The best way to do this is to calculate imputed land rents.

Imputed land rents in this data set can be determined using the following procedure. For the two districts (Faisalabad and Badin) which have only irrigated 1 and, it is necessary to determine median annual land rents per acre (for land rented out) in each district. For the two districts (Attock and Dir) which have both irrigated and rainfed land, average annual land rents per acre (for 1 and rented out) can he determined using the following regression:

TOTRENT $_{h i}=f\left(\right.$ ACIRR $_{h 1}$, ACRAIN $\left._{h i}\right)$,

where TOTRENT = Total value of land rent received by household $h$ in district $i$

$A C I R R=$ Total acres of irrigated land rented out by household $h$ in district $i$

ACRAIN = Total acres of rainfed land rented out by household $h$ in district $i$

Equation (9) was run separately for each district with irrigated and rainfed land (Attock and Dir). In this equation the regression coefficients for the independent variables (ACIRR and ACRAIN) represent the average annual land rents per acre for irrigated and rainfed land, respectively.

For each year of the survey total annual imputed land rent can then be calculated as the product of household values for two terms: average annual 1 and rent per acre ${ }^{13}$ and the number of acres cultivated. 14

Once imputed land rent is calculated, total agricultural income in the study can be divided into four sources: 
(1) Imputed land rent

(2) Land rent - Includes rent received for the leasing of 1 and;

(3) Agricultural wages - Includes payments in wages and kind for agricultural work;

(4) Other income - Includes returns to labor and crop profit.

Table 6 presents summary data for the four sources of agricultural income over the three survey years. The data show that other agricultural income (returns to labor and crop profit) represents the most important source of mean per capita agricultural income in all three years. By contrast, it is interesting to note the relative unimportance of agricultural wages: agricultural wages represent less than 4 percent of total mean per capita agricultural income in any given year. In the sample area the widespread sharing of agricultural labor between and among families apparently serves as a substitute for the hiring of wage labor. ${ }^{15}$

Table 7 reports the decomposition results with respect to the distinction between inequality-increasing and inequality-decreasing sources of agricultural income. With only one exception in each case, both decompositions agree that two income sources -. 1 land rent and other agricultural income (returns to labor and crop profit) -represent inequality-increasing sources of agricultural income. Both decompositions also agree that two income sources -. imputed land rent and agricultural wages -- represent inequality-decreasing sources of agricultural income. Given the widespread belief that landownership - here measured in terms of imputed 1 and rent .. represents an inequality-increasing source of income, these results are surprising and will be examined below. 
Table 8 presents the decomposition results for relative factor inequality weights of source incomes in agricultural inequality. Aga in the results suggest that unequal landownership does not represent a major source of agricultural income inequality. This may be seen in two ways. First, both decompositions agree that for all three years other agricultural income (returns to labor and crop profit) makes the largest contribution to agricultural income inequality. According to the data, other agricultural income accounts for between 42.6 and 68.4 percent of agricultural income inequality. Second, with only one exception both decompositions agree that for all three years landownership .- here measured by combining imputed land rent and 1 and rent -. makes a smaller contribution than other agricultural income (returns to labor and crop profit) to agricultural inequality. Combining the factor inequality weights for imputed 1 and rent and land rent together, the data suggests that landownership accounts for between 31.6 and 57.0 percent of agricultural income inequality. Given the common view that unequal landownership plays a dominant role in rural income inequality, these results require elaboration.

The results in Table 8 can be explained by presenting the three elements of the Gini decomposition: (1) source income weight; (2) source gini; and (3) correlation ratio between source income and total income inequality. This is done in Table 9.

According to row (2) of Table 9, other agricultural income (returns to labor and crop profit) has the highest source gini in two of the three years. In fact, in two years the ginis for this income source exceed 1.0. ${ }^{16}$ By contrast, the other sources of agricultural 
incume are distributed more equally. Row (3) of Table 9 shows that the correlation ratio between source income and total income inequality is highest for two income sources: land rent and other agricultural income. By contrast, inequality in imputed land rent is poorly correlated with total income inequality and inequality in agricultural wages is very weakly correlated with total agricultural income inequality.

The data in Table 9 serve to explain why unequal landownership does not play a dominant role in agricultural income inequality in this sample. While the source income weights for landownership.measured by combining the values for imputed land rent and 1 and rent - generally exceed those for other agricultural income, the source ginis and correlation ratios for these two income sources are on the whole less than those for other agricultural income. In this sample other agricultural income (returns to labor and crop profit) represents the main source of agricultural income inequality. This is because other agricultural income (returns to labor and crop profit) has a large share of total agricultural income, a large source gini and is highly correlated with total agricultural inequality.

\section{Conclusion}

This paper has examined the sources of income inequality in rural Pakistan. Using three-year time series data from 727 households in three provinces, this study decomposed both the sources of overall income inequality and the sources of agricultural income inequality.

Two central findings emerge from the paper. First, the study shows that, of the five sources of total rural income -- agricultural, 
livestock, rental, non-farm, and transfer .- agricultural income makes the largest contribution to overall income inequality. This is because agricultural income has a large share of total income, a middle-sized source gini and is moderately correlated with overall income inequality. At the other extieme, the study shows that livestock income makes the smallest contribution to overall income inequality. This latter finding suggests an important oolicy conclusion, namely, that policymakers who are concerne. th income inequality in rural Pakistan would be well-advised to pay more attention to livestock. According to this study, livestock income represents an inequality-decreasing source of income because it has a middle-sized share of total income, a low source gini and is poorly correlated with overall income inequality.

Second, this study decomposes the sources of agricultural income inequality in order to understand how much of this inequality is caused by unequal landownership. In the study area landownership and landholdings are quite skewed; both are distributed far more unequally than income. ${ }^{17}$ However, rather surprisingly, the study shows that unequal landownership -- as measured by imputed land rent and 1 and rent -. does not represent the main source of agricultural income inequality. Acco.ding to the study, the main source of agricultural income inequality is other agricultural income (returns to labor and crop profit). According to the data, other agricultural income accounts for between 43 and 52 percent of agricultural income inequality.

It is important to realize that this finding concerning the relative unimportance of landownership in determining agricultural 
income inequality is consistent with the results of other studies. Using similar methodologies, other studies of the sources of income inequality in laiwan, Pakistan and Colombia have found that the bulk of such inequality comes from labor .. and not property or 1 and -. income. ${ }^{18}$ On the basis of these studies, Fields (1980: 114) concludes:

The bulk of income inequality is attributable to labor income. (According to these studies) the principal inequality-producing factor is that some people receive a great deal more income for their work than do others. . The intuitive prior notion that the most unequally distributed factors (such as property) contribute the most to total inequality is found to be false. .

In this study it was impossible to decompose other agricultural income (returns to labor and crop profit) in order to identify the contribution of labor income .. as opposed to crop income -. to agricultural inequality. Nevertheless, the study's finding that returns to labor and crop profit represent the main source of agricultural income inequality has important implications for policymaking. Most basically, it suggests that increased attention needs to be paid to the techniques and technologies of crop production in Pakistan. If the goal is to reduce income inequalities in rural Pakistan, researchers and policymakers need to find ways to narrow the disparities in human capital (including managerial and technical skills) between different agriculturalists. 
Notes

*The authors are grateful to Dipa Nag-Chowdhury and Jane He for valuable computer assistance, and to Marjory-Anne Bromhead, Aly Ercelawn and Gary Fields for insightful comments.

1. On Pakistan, see Kruijk (1987), Mohammad and Badar (1985) and Ercelawn (1984); on other developing countries, see Glewwe (1986), Nugent and Walther (1982) and Pyatt, Chen and Fei (1980).

2. Among the decomposition studies cited in note (1), only Nugent and Walther (1982) use panel data in ungrouped (disaggregated) form to examine short-run fluctuations in the sources of rural income inequality.

3. For an overview of these four inequality measures, see Anand (1983: 89-91).

4. This study eas undertaken by the International Food Policy Research Institute (IFPRI) working in collaboration with Pakistani research institutes -. Applied Economic Research Centre (University of Karachi), Punjab Economic Research Institute (Lahore), the University of Baluchistan (Quetta) and the Center for Applied Economic Studies (University of Peshawar).

5. The sample was randomly drawn with all rural residents in the selected districts having an equal probability of being included. Landowners who reside in urban areas, therefore, are not included in the sample. Since unweighted samples generally tend to miss the apex of a distribution, the fact that there are, for example, far fewer households owning 3,000 acres of 1 and than there are households owing 3 acres may lead to a slight underrepresentation of the skew of landholding in any moderately sized sample.

6. The 727 households were distributed among the districts as follows: 148 from Attock District (Punjab), 239 from Badin District (Sind), 193 from Dir District (Northwest Frontier) and 147 from Faisalabad District (Punjab).

7. The Gini coefficients of household income recorded for ten Asian countries in Lecailion et. al (1984: Table 3) range from a low of 0.351 (Korea) to a high of 0.561 (Iran). It should, however, be noted 
that the Gini coefficients for these Asian countries are based on the distribution of overall (i.e. rural and urban), while the Ginis used in this study are based on rural household income. In theory, one would expect that the distribution of rural household income to be more egalitarian than that of overall household income. See Lecaillon et. al (1984: 67-68).

8. For Pakistan, see Klennert (1986); for other developing countries see von Braun and Pandya-Lorch (1991).

9. This -nalysis ignores feedback effects, that is, the effects that a change in any source income share might have on distribution within any source income. Of course, such an assumption might be quite unrealistic for large changes in any source income share.

10. As Ercelawn (1984: 7) has shown, this contradiction occurs either when $c_{1}<1$ and $g_{1} \geq 1$ or when $c_{i} \geq 1$ and $g_{1}<1$. The contradiction seems to reflect the greater sensitivity of the Gini to middle-income groups and of the coefficient of variation to extreme incomes.

11. Both of these Gini calculations include households with no 1 and. Landownership and landholdirgs do not include waste land.

Landholdings include land owned plus 1 and rented in minus land rented out.

For households with land in the sample, mean landownership is 11.44 acres with a standard deviation of 18.19; mean landholdings is 9.70 acres with a standard deviation of 12.15 .

12. For Pakistan, see Ercelawn (1984) and Naqvi, Khan and Chaudhry (1989). For other developing countries, see Quan (1989) and Bardhan (1984).

13. Using the procedures outlined in the text, average annual land rents per acre varied (low to high) as follows: Faisalabad District (Punjab), from 1234.3 rupees in 1988-89 to 1528.8 rupees in 1986-87; rainfed areas of Attock District (Punjab), from 10.2 rupees in 1986-87 to 117.2 rupees in 1987-88; irrigated areas of Attock, from 366.3 rupees in 1987-88 to 540.4 rupees in 1988-89; Badin District (Sind), from 874.2 rupees in 1988-89 to 904.1 rupees in 1987-88; rainfed areas of Dir District (Northwest Frontier), from 144.3 in 1986-87 to 815.9 rupees in 1988-89; and irrigated areas of Dir District, from 177.1 rupees in 1986-87 to 978.5 rupees in 1988-89. In all districts the variability in rental prices reflects, in part, the fact that most rental agreements are for sharecropping rather than fixed rents. All rental prices are in constant 1986 rupees.

14. For each household, number of acres cultivated equals 1 and owned minus land rented out. In all districts except Badin, land rental area is based on area rented out in rabi (winter) season. For Badin District land rental area is based on area rented out in kharif (monsoon) season.

15. For a discussion of this point, see Nabi et. al (1986). 
-22 .

16. For an explanation of this outcome, see note (a) in Table 9.

17. As noted in the text, the Gini coefficients of landownership and landholdings in th: study area are 0.769 and 0.630 ; respectively. In contrast, the Gini coefficients of per capita household income range (according to year) from 0.384 to 0.417 .

18. On Taiwan, see Fei, Ranis and Kuo (1978); on Pakistan, see Ayub (1977) and Kruijk (1987); and on Colombia, see Fields (1979). 


\section{REFERENCES}

Anand, Sudhir. (1983). Inequality and Poverty in Malays:a:

Measurement and Decomposition, Oxford University Press, New York.

Ayub, Mahmud. (1977). Income Inequality in a Growth-Theoretic

Context: The Case of Paxistan, Yale University, Department of

Economics, unpublished Ph.D. dissertation.

Bardhan, Pranab. (1984). Land, Labor and Rural Poverty: Essays in

Development Economics, Columbia University Press, New York.

von Braun, Joachim and Rajul Pandya-Lorch, eds. (1990). Income

Sources of Malnourished People in Rural Areas: Microlevel

Information and Policy Implications, Working Papers on

Commercialization of Agriculture and Nutrition 5, International

Food Policy Research Institute, Washington, D.C.

Ercelawn, Aly. (1984). 'Income Inequality in Rural Pakistan: A Study

of Sample Villages', Pakistan Journal of Applied Economics, Vol.

3, No. 1, pp. 1-28.

Fei, John, Gustav Ranis and Shirley Kuo. (1978). 'Growth and the

Family Distribution of Income by Factor Components', Quarterly Journal of Economics, Vol. 42, No. 1, pp. 17-53.

Fields, Gary. (1979). 'Income Inequality in Urban Colombia: A

Decomposition Analysis', Revizw of Income and Wealth, Vol. 25, No. $3, \mathrm{pp}, 327-341$.

Fields, Gary. (1980). Poverty, Inequal ity and Development, Cambridge University Press, New York. 
Foster, James. (1985). 'Inequality Measurement' in Fair Allocation, ed. H. Peyton Young, Vol. 33, Proceedings of Symposia in Applied Mathematics, American Mathematical Society, Providence, RI. Glewwe, Paul. (1986). 'The Distribution of Income in Sri Lanka in 1969-70 and 1980-81: A Decomposition Analysis', Journal of Development Economics, Vol. 24, pp. 255-274.

Kakwani, N.C. (1980). Income Inequality and Poverty, oxford University Press, New York.

Klennert, K. (1985). 'Off-Farm Employment in Marginal Farm Households: A Hidden Development of Parts of Pakistan's Rural Poor', Quarterly Journal of International Agriculture, Vol. 25, pp. 37-48.

Kruijk, Hans de. (1987). 'Sources of Income Inequality in Pakistan', Pakistan Development Review, Vol. 26, pp. 659-672.

Kuznets, Simon. (1955). 'Economic Growth and Income Inequality', American Economic Review, Vol. 45, pp. 1-28.

Kuznets, Simon. (1963). 'Quantitative Aspects of the Economic Growth of Nations: Distribution of Income by Size', Economic Development and Cultural Change, Vol. 11, pp. 1-80.

Lecaillon, Jacques, F. Paukert, C. Morrisson and D. Germidis. (1984). Income Distribution and Economic Development: An Analytical

Survey, International Labour Office, Geneva.

Lerman, Robert and Shlomo Yitzhaki. (1985). 'Income Inequality Effects by Income Source: A New Approach and Applications to the United States', Review of Economics and Statistics, Vol. 62. No. 1, pp. $151-156$. 
Mohammad, Faiz and Ghulam Badar. (1985). 'Structure of Rural Income in Pakistan: Some Preliminary Estimates', Pakistan Development Review, Vol. 24, No. 3, pp. 385-403.

Nabi, Ijaz, Naveed Hamid, and Shahid Zahid. (1986). The Agrarian

Economy of Pakistan, Oxford University Press, Karachi, Pakistan. Naqui, Syed, Mahmood Khan and M. Ghaffar Chaudhry. (1989).

Structural Chonge in Pakistan's Agriculture, Pakistan Institute of Deveropment Economics, Islamabad, Pakistan.

Nugent, Jeffrey and Robin Walther. (1982). 'Short-Run Changes in

Rural Income Inequality: A Decomposition Analysis', Journal of

Development Studies, Vol. 18, No. 2, pp. 239-269.

Pasha, Mafiz and Tariq Hasan. (1982). 'Development Ranking of

Districts of Pakistan', Pakistan Journal of Applied Economics, Vo1. 1, No. 2, pp. 157-192.

Pyatt, Graham, Chau-Nan Chen and John Fei. (1980). 'The Distribution of Income by Factor Components', Quarterly Journal of Economics, Vol. 95 , No. 3 , pp.451-473.

Quan, Nguyen. (1989). 'Concentration of Income and Land Holdings: Prediction by Latent Variables Model and Partial Least Squares', Journal of Development Economics, Vol. 31, pp. 55-76.

Shorrocks, A. F. (1983). 'The Impact of Income Components on the Distribution of Family Income', Quarterly Journal of Economics, Vol. 98 , No. 2, pp. 311-326.

Shorrocks, A. F. (1982). 'Inequality Decomposition by Factor Components', Econometrica, Vol. 50, No. 1, pp. 193-211. 
Table 1 -- Sumary of Income Data from 1986 87, 1987-88 and 1988-89 Surveys in Rural Pakistan

\begin{tabular}{|c|c|c|c|c|c|c|}
\hline & \multicolumn{2}{|c|}{$1986-87$} & \multicolumn{2}{|c|}{$1987-88$} & \multicolumn{2}{|c|}{ 1988-89 } \\
\hline $\begin{array}{l}\text { Source } \\
\text { of } \\
\text { Incone }\end{array}$ & $\begin{array}{l}\text { Mean Annual } \\
\text { Per Capita } \\
\text { Household } \\
\text { Income" in } \\
\text { Rupees" }\end{array}$ & $\begin{array}{l}\text { Standard } \\
\text { Deviat ion }\end{array}$ & $\begin{array}{l}\text { Mean Annual } \\
\text { Per Capita } \\
\text { Household } \\
\text { Income }^{*} \text { in } \\
\text { Rupees }^{\text {a. }}\end{array}$ & $\begin{array}{l}\text { Standard } \\
\text { Deviat ion }\end{array}$ & $\begin{array}{l}\text { Mean Annual } \\
\text { Per Capita } \\
\text { Household } \\
\text { Incone in } \\
\text { Rupees" }\end{array}$ & $\begin{array}{l}\text { Standard } \\
\text { Deviat ion }\end{array}$ \\
\hline Mon-farm & 1028.75 & 1271.98 & 1142.97 & 1283.92 & 921.54 & 1009.31 \\
\hline Agricu'tural & 831.38 & 1997.31 & 862.14 & 1632.01 & 885.35 & 2377.22 \\
\hline Iransfer & 596.82 & 1592.44 & 525.29 & $146 i .70$ & 242.91 & 812.57 \\
\hline I ivestock & 587.69 & 726.39 & 541.82 & 787.69 & 421.81 & 685.24 \\
\hline Rental & 408.49 & 1556.63 & 412.43 & 1366.50 & 446.86 & 1500.70 \\
\hline Total & 3453.12 & 3186.68 & 3484.65 & 3009.24 & 2918.47 & 3320.57 \\
\hline
\end{tabular}

$M=727$ households

Notes: (a) Mean income figures include negat ive source incomes recorded for same households in various years.

(b) In 1986. I Pakistani Rupee = US\$0.062. All rupee figures in constant 1986 terms. 
Table 2 - Sources of Income by Mean Annual Per Capita Household Income Quintile Group

\begin{tabular}{|c|c|c|c|c|c|c|}
\hline $\begin{array}{l}\text { Income Quintile } \\
\text { Group }\end{array}$ & $\begin{array}{l}\text { Mean Annual } \\
\text { Per Capita } \\
\text { Household } \\
\text { Income }{ }^{a /} \text { in } \\
\text { Rupees }^{b /}\end{array}$ & $\begin{array}{l}\text { Percent from } \\
\text { Non-farm } \\
\text { Income }\end{array}$ & $\begin{array}{l}\text { Percent from } \\
\text { Agricultural } \\
\text { Income }\end{array}$ & $\begin{array}{l}\text { Percent } \\
\text { from } \\
\text { Transfer } \\
\text { Income }\end{array}$ & $\begin{array}{l}\text { Percent } \\
\text { from } \\
\text { Livestock } \\
\text { Income }\end{array}$ & $\begin{array}{l}\text { Percent } \\
\text { from } \\
\text { Rental } \\
\text { Income }\end{array}$ \\
\hline Lowest $20 \%$ & 1231.94 & 40.8 & 20.6 & 11.1 & 23.2 & 4.3 \\
\hline Second $20 \%$ & 1971.29 & 43.5 & 22.2 & 11.7 & 18.5 & 4.1 \\
\hline Third $20 \%$ & 2603.89 & 36.0 & 25.9 & 10.2 & 22.7 & 5.2 \\
\hline Fourth $20 \%$ & 3540.92 & 40.4 & 23.6 & 13.2 & 16.5 & 6.3 \\
\hline Highest $20 \%$ & 7051.29 & 20.1 & 29.6 & 16.6 & 10.8 & 22.9 \\
\hline Total & 3279.87 & & & & & \\
\hline
\end{tabular}

$N=727$ households

Notes:

a/ Mean income figures calculated by averaging household income over the three years (1986-87 to 1988-89) and then dividing by average household size.

b/In 1986, I Pakistani Rupee = US \$0.062. All rupee figures in constant 1386 terms. 
Iable 3 - Decomposition of Inequal ity: Relat ive Concentration Coefficients of Source Incomes in Overall Inequality

$1986 \cdot 8 i$

\begin{tabular}{|c|c|c|c|}
\hline $\begin{array}{l}\text { Source } \\
\text { of } \\
\text { Incone }\end{array}$ & $\begin{array}{l}\text { Coefficient } \\
\text { of } \\
\text { Variation }\end{array}$ & $\begin{array}{c}\text { Gini } \\
\text { Coeftic rent }\end{array}$ & $\begin{array}{c}\text { Coefficient } \\
\text { of } \\
\text { Variat ion }\end{array}$ \\
\hline & $\cdots \quad \ldots$ & $\cdots$ & $\ldots$ \\
\hline
\end{tabular}

$1987-88$

1988-89

Gini
Coefficient

Gin 1

Variation

Coeff ic ient"

$\begin{array}{lllllll}\text { Won farm } & 0.199 & 0.703 & 0.187 & 0.595 & 0.204 & 0.664 \\ \text { Agricultural } & 1.377 & 1.118 & 1.235 & 1.121 & 1.390 & 1.214 \\ \text { Transter } & 1.655 & 1.306 & 1.179 & 1.364 & 0.692 & 1.222 \\ \text { I rvestock } & 0.183 & 0.521 & 1.039 & 0.871 & 0.017 & 0.614 \\ \text { Rental } & 2.463 & 1.792 & 2.557 & 1.697 & 2.995 & 1.665\end{array}$

N - 727 households

Notes:

All est imates based on annual per capita household income expressed in constant 1986 terms.

"Concentration of coefficient of inequality: $c_{1}=\rho_{1} \frac{\sigma . / \mu \text {. }}{\sigma / \mu}$

"Concentration of $6 \mathrm{In}$ i coefficient: $g .=R_{\frac{G}{G}}$ 
Table 4 - Decomposition of Inequality: Factor Inequality Heights of Source Incones in Overall Inequality

\begin{tabular}{|c|c|c|c|c|c|c|c|c|c|c|c|}
\hline \multicolumn{4}{|c|}{$1986-87$} & \multicolumn{3}{|c|}{$1987-88$} & \multicolumn{5}{|c|}{$1988-89$} \\
\hline $\begin{array}{l}\text { Source } \\
\text { of } \\
\text { Incoine }\end{array}$ & $\begin{array}{l}\text { Coefficient } \\
\text { of } \\
\text { Variation }\end{array}$ & $\begin{array}{l}\text { Source } \\
\text { of } \\
\text { Incoun }\end{array}$ & $\operatorname{coefficient}^{\mathrm{b} /}$ & $\begin{array}{l}\text { Source } \\
\text { of } \\
\text { Incoune }\end{array}$ & $\begin{array}{l}\text { Coeff ic ient } \\
\text { of } \\
\text { Varlat } \operatorname{Ion}^{a /}\end{array}$ & $\begin{array}{l}\text { Source } \\
\text { of } \\
\text { Incone }\end{array}$ & $\operatorname{coefini}_{\text {Colent }}^{b /}$ & $\begin{array}{c}\text { Source } \\
\text { of } \\
\text { Incane }\end{array}$ & $\begin{array}{l}\text { Coefficient } \\
\text { of } \\
\text { Variat ton }\end{array}$ & $\begin{array}{l}\text { Source } \\
\text { of } \\
\text { Incone }\end{array}$ & $\underset{\text { Coefficient }}{\text { Gini }}$ \\
\hline Agricultural & 0.332 & Agricultural & 0.269 & Agricultural & 0.305 & Agricultural & 0.277 & Rental & 0.459 & Agricultural & 0.368 \\
\hline Rental & 0.291 & Transfer & 0.226 & Rental & 0.298 & Transfer & 0.205 & Agricultural & 0.422 & Rental & 0.255 \\
\hline Transfer & 0.285 & Renta 1 & 0.211 & Transfer & 0.178 & Rental & 0.200 & Mon-farm & 0.064 & Non-farm & 0.208 \\
\hline Mon-farm & 0.059 & Mon-farm & 0.209 & Livesinck & 0.162 & Mon-farm & 0.194 & Transfer & 0.058 & Transfer & 0.101 \\
\hline L Irestock & 0.031 & Livestock & 0.085 & Mon-farm & 0.060 & L ivestock & 0.135 & I ivestock & 0.002 & Livestock & 0.087 \\
\hline TOTAL & 1.000 & & 1.000 & & 1.000 & & 1.000 & & 1.000 & & 1.000 \\
\hline
\end{tabular}

$N=727$ households

Motes:

A11 est inates based on annual per capita household income expressed in constant 1986 terms.

a/Factor inequality wight for coefficient of variation: $\omega_{i} c_{i}$, where $w_{i}=\frac{\mu_{1}}{\mu}, c_{i}=\rho_{i} \frac{\sigma_{i} / \mu_{i}}{\sigma / \mu}$

b/Factor inequality weight for Gini coefficient: $g_{i}$, where $w_{i}=\frac{\mu_{1}}{\mu}, g_{i}=R_{i} \frac{G_{i}}{G}$ 
Table 5 - Decomposition of Overall Income Inequal ity Using Gini Coefficient

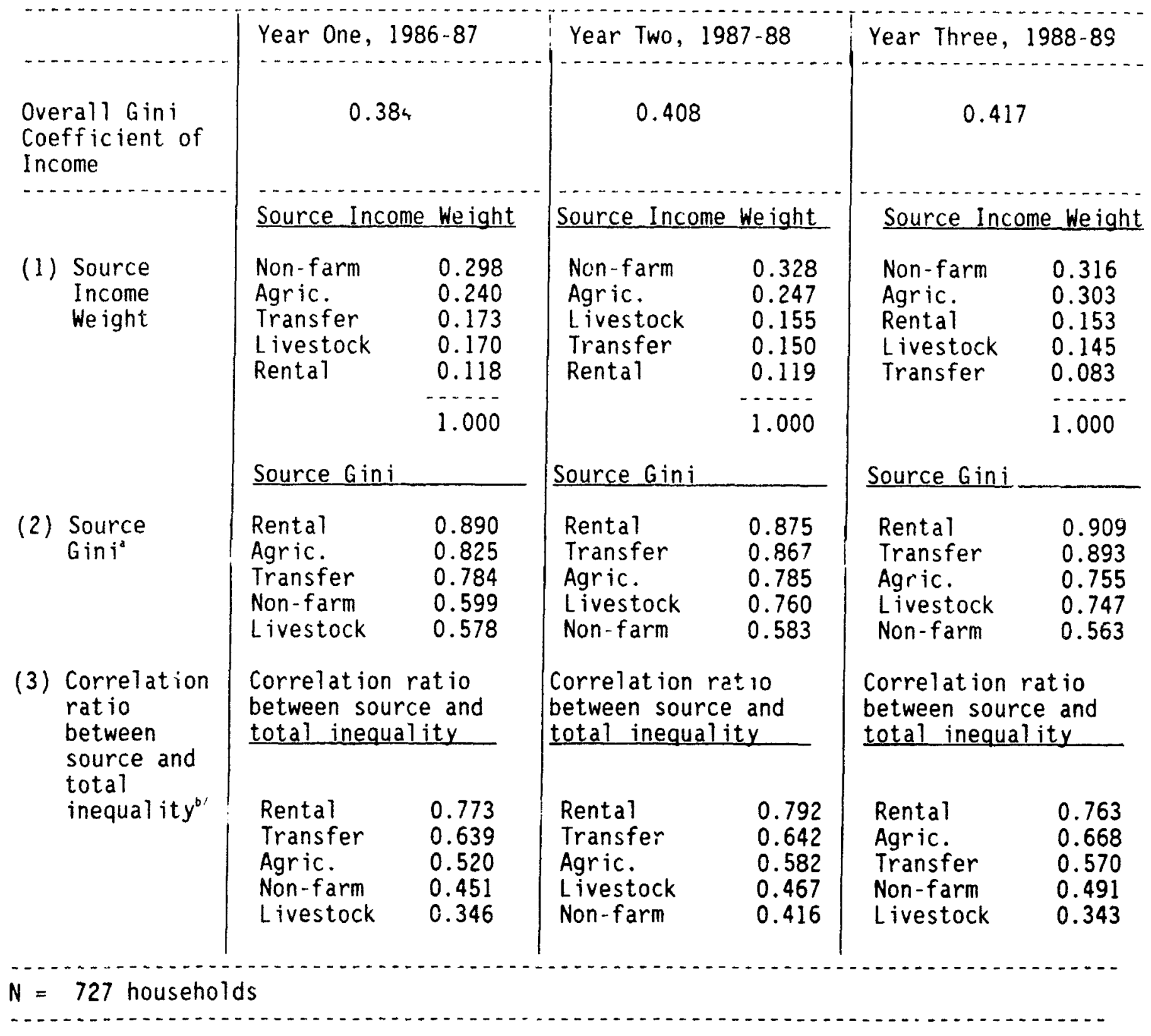

Notes: All estimates based on annual per capita household income expressed in constant 1986 terms.

"Source Gini, $G_{1}=\frac{2}{n \mu_{1}} \operatorname{cov}\left(y_{1}, r_{1}\right)$

${ }^{b / C o r r e l a t i o n ~ r a t i o ~ b e t w e e n ~ s o u r c e ~ a n d ~ t o t a l ~ i n e q u a l i t y, ~}$

$$
R_{1}=\frac{\operatorname{cov}\left(y_{1}, r\right)}{\operatorname{cov}\left(y_{1}, r_{1}\right)}=\frac{\begin{array}{c}
\text { covariance between source income amount } \\
\text { and total income rank }
\end{array}}{\begin{array}{c}
\text { covariance between source income amount } \\
\text { and source income rank }
\end{array}}
$$


Table 6 -- Sumary of Agricultural Incame Data fram 1986-87, 1987-88 and 1988-89 Surveys

\begin{tabular}{|c|c|c|c|c|c|c|}
\hline & \multicolumn{2}{|c|}{$1986-87$} & \multicolumn{2}{|c|}{$1987-88$} & \multicolumn{2}{|c|}{$1988-89$} \\
\hline $\begin{array}{l}\text { Source } \\
\text { of } \\
\text { Income }\end{array}$ & $\begin{array}{l}\text { Mean Annual } \\
\text { Per Capita } \\
\text { Household } \\
\text { Incone jn } \\
\text { Rupees }\end{array}$ & $\begin{array}{l}\text { Standard } \\
\text { Deviat ion }\end{array}$ & $\begin{array}{l}\text { Hean Annual } \\
\text { Per Capita } \\
\text { Household } \\
\text { Incone jn } \\
\text { Rupees }\end{array}$ & $\begin{array}{l}\text { Standard } \\
\text { Deviation }\end{array}$ & $\begin{array}{l}\text { Mean Annual } \\
\text { Per Capita } \\
\text { Household } \\
\text { Incone in } \\
\text { Rupees }\end{array}$ & $\begin{array}{l}\text { Standard } \\
\text { Deviation }\end{array}$ \\
\hline $\begin{array}{l}\text { Imputed Land } \\
\text { Rent }\end{array}$ & 325.81 & 937.83 & 317.43 & 951.79 & 286.89 & 816.14 \\
\hline Land Rent & 281.82 & 1269.37 & 298.40 & 1076.65 & 317.47 & 1125.13 \\
\hline $\begin{array}{l}\text { Agricultural } \\
\text { t'ages }\end{array}$ & 32.34 & 132.19 & 46.29 & 209.52 & 30.55 & 94.93 \\
\hline $\begin{array}{l}\text { Other (Returns } \\
\text { to labor: } \\
\text { crop prof it) }\end{array}$ & 488.16 & 1620.34 & 537.31 & 1263.47 & 639.65 & 2190.26 \\
\hline Total & 1128.13 & 2439.15 & 1199.42 & 2064.42 & 1274.56 & 2772.99 \\
\hline
\end{tabular}

Notes: Figures based on 680 households wich represent those households fram the original 727 households with positive agricultural incomes in any year of three survey years.

(a) All rupee figures in constant 1986 terns

(b) Total agricultural income figures in this table differ

from those in Table 1 because "agricultural income"

here includes land rent. In Table 1 land rent is included

in "rental income." not "agricultural incone." See text. 
Table 7 -- Relative Concentration Coefficients of Source Incomes in Total Agricultural Income

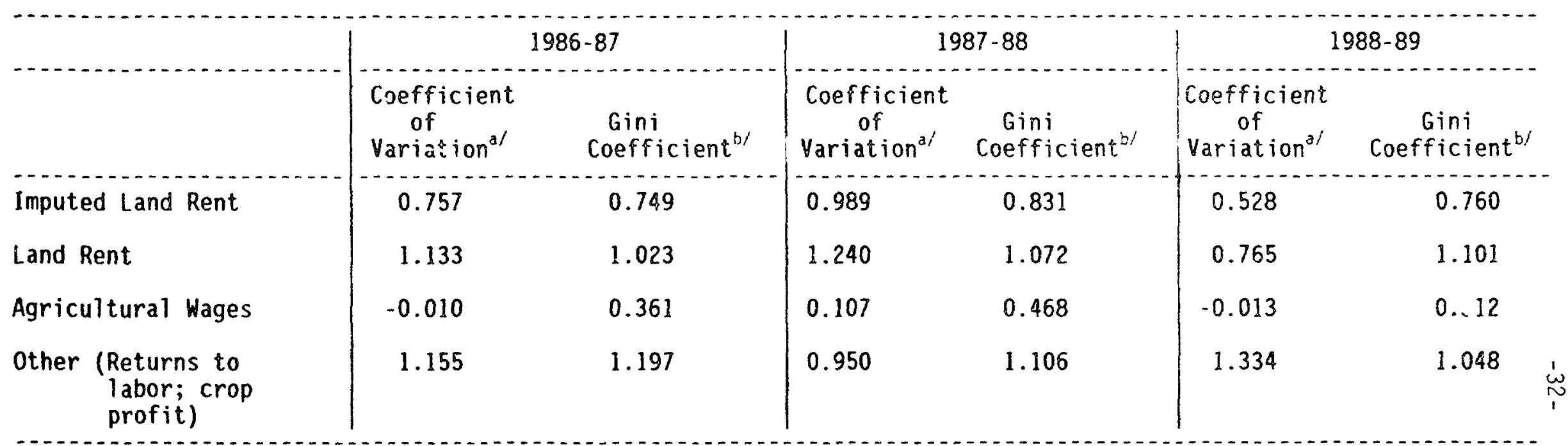

Notes: Calculations based on 680 households which represent those households from the original 727 households with positive agricultural incomes in any year of three survey years.

All estimates based on annual per capita household income expressed in constant 1986 terms.

${ }^{a / C o n c e n t r a t i o n ~ o f ~ c o e f f i c i e n t ~ o f ~ v a r i a t i o n: ~} c_{1}=\rho_{i} \frac{\sigma i / \mu i}{\sigma / \mu}$

${ }^{b / C o n c e n t r a t i o n ~ o f ~ G i n i ~ c o e f f i c i e n t: ~} g_{i}=R_{i} \frac{G_{i}}{G}$ 
Table 8 -- Factor Inequality Weights of Source Incones in Total Agricultural Incone

\begin{tabular}{|c|c|c|c|c|c|c|}
\hline & \multicolumn{2}{|c|}{$1986-87$} & \multicolumn{2}{|c|}{$1987-88$} & \multicolumn{2}{|c|}{$1988-89$} \\
\hline & $\begin{array}{c}\text { Coeff ic ient } \\
\text { of } \\
\text { Variation }\end{array}$ & $\begin{array}{c}\text { Gini } \\
\text { Coefficient }\end{array}$ & $\begin{array}{c}\text { Coefficient } \\
\text { of } \\
\text { Yariation }\end{array}$ & $\begin{array}{c}\text { Gini } \\
\text { Coeff icient }\end{array}$ & $\begin{array}{c}\text { Coefficient } \\
\text { of } \\
\text { Variation }\end{array}$ & $\begin{array}{l}\text { Gini } \\
\text { Coefficient }\end{array}$ \\
\hline Imputed Land Rent & 0.219 & 0.216 & 0.262 & 0.220 & 0.121 & 0.175 \\
\hline Land Rent & 0.282 & 0.256 & 0.308 & 0.267 & 0.195 & 0.280 \\
\hline Agricu ltural Vages & 0.001 & 0010 & 0.004 & 0.018 & 0.001 & 0.008 \\
\hline $\begin{array}{c}\text { Other (Returns to labor: } \\
\text { crop prof it) }\end{array}$ & 0.500 & 0.518 & 0.426 & 0.495 & 0.684 & 0.537 \\
\hline TOTAL & 1.000 & 1.000 & 1.000 & 1.000 & 1.000 & 1.000 \\
\hline
\end{tabular}

Motes: Calculations based on 680 households hich represent those households from the original 727 househo ids with positive agricultural incomes in any year of three survey years.

All est imates based on annual per capita household income expressed in constant 1986 terms. 
Table 9 - Decomposition of Agricultural Income Inequality Using Gini Coefficient

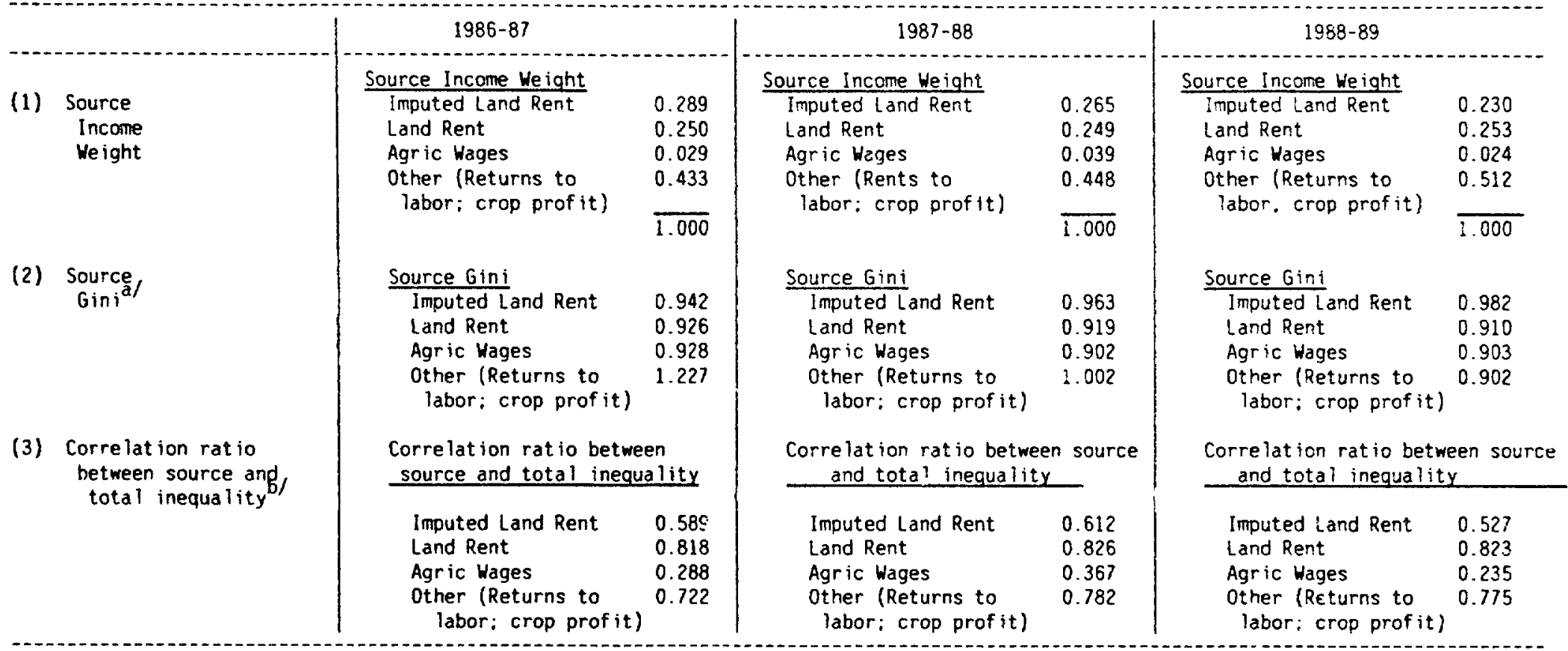

Notes: Calculations based on 680 households which represent those households from the original 727 hcuseholds with positive agricultural incomes in any year of the three survey years.

All est imates based on annual f r capita household income expressed in constant 1986 terms.

a/Source Gini, $G_{i}=\frac{2}{n \mu_{i}} \operatorname{cov}\left(y_{i}, r_{i}\right)$. Source Ginis can exceed unity if some of $y_{i}$ are negative.

b/Correlation ratio between source and total inequality.

$$
R_{i}=\frac{\operatorname{cov}\left(y_{i}, r\right)}{\operatorname{cov}\left(y_{j}, r_{j}\right)}=\frac{\begin{array}{c}
\text { covariance between source income amount } \\
\text { and total income rank }
\end{array}}{\begin{array}{c}
\text { covariance between source income amount } \\
\text { and source income rank }
\end{array}}
$$


$\begin{array}{lll}\text { Iithe Contact } & \text { Dather } \\ \text { Leroaper }\end{array}$

\begin{tabular}{|c|c|c|c|c|}
\hline WPS814 & Finance, Growth, and Public Policy & $\begin{array}{l}\text { Mark Gertler } \\
\text { Andrew Rose }\end{array}$ & December 1991 & $\begin{array}{l}\text { W. Pitayatonakarn } \\
37666\end{array}$ \\
\hline WPS815 & Governance and Economy. A Review & Deborah Brautigam & December 1991 & $\begin{array}{l}\text { Z. Kranzer } \\
37494\end{array}$ \\
\hline WPS\$16 & $\begin{array}{l}\text { Econsmic Consequences of German } \\
\text { Reunification: } 12 \text { Montrs After the Big } \\
\text { Bang }\end{array}$ & Gerhard Pohl & December 1991 & $\begin{array}{l}\text { CECSE } \\
37188\end{array}$ \\
\hline WPS817 & $\begin{array}{l}\text { How Does Brady-Type Commercial } \\
\text { Debi Restructuring Work? }\end{array}$ & Mohua Mukherjee & December 1991 & $\begin{array}{l}\text { Y. Arellano } \\
31379\end{array}$ \\
\hline WPS818 & $\begin{array}{l}\text { Do Rules Control Power? GATT } \\
\text { Articles and Arrangements in the } \\
\text { Uruguay Found }\end{array}$ & $\begin{array}{l}\text { J Michael Finger } \\
\text { Sumana Driar }\end{array}$ & January 1992 & $\begin{array}{l}\text { N. Artis } \\
37947\end{array}$ \\
\hline WPS819 & $\begin{array}{l}\text { Financial Indicators and Growth in a } \\
\text { Cross Sectic n of Countries }\end{array}$ & $\begin{array}{l}\text { Robert G. Kıng } \\
\text { Ross Levine }\end{array}$ & January 1932 & $\begin{array}{l}\text { W. Pitayatonakarn } \\
37666\end{array}$ \\
\hline WPS320 & $\begin{array}{l}\text { Taxation in Decentralızıng Socialıst } \\
\text { Economies: The Case of China }\end{array}$ & $\begin{array}{l}\text { Christopher Heady } \\
\text { Pradeep K Mitra }\end{array}$ & January 1992 & $\begin{array}{l}\text { D. Sebastian } \\
80423\end{array}$ \\
\hline WPS821 & $\begin{array}{l}\text { Wages and Unemployment in Poland: } \\
\text { Recent Developments and Policy } \\
\text { Issues }\end{array}$ & $\begin{array}{l}\text { Fabrizio Ccricellı } \\
\text { Ana Revenga }\end{array}$ & January 1992 & $\begin{array}{l}\text { V. Bertinelmes } \\
39175\end{array}$ \\
\hline WPS822 & $\begin{array}{l}\text { Paternalism and the Alleviation of } \\
\text { Poverty }\end{array}$ & Riancy Jesurun-Clements & January 1992 & $\begin{array}{l}\text { F. Betancourt } \\
18-126\end{array}$ \\
\hline WPS823 & $\begin{array}{l}\text { How Private Enterprise Crganized } \\
\text { Agricultural Markets in Kenya }\end{array}$ & Steven $M$. Jaffee & January 1992 & $\begin{array}{l}\text { C. Spooner } \\
30464\end{array}$ \\
\hline WPS824 & $\begin{array}{l}\text { Back-of-the-Envelope Estimates } \\
\text { of Environmental Damage Costs in } \\
\text { Mexico }\end{array}$ & Sergio Margulis & January 1992 & $\begin{array}{l}\text { J. Arevalo } \\
30745\end{array}$ \\
\hline WPS825 & $\begin{array}{l}\text { The Empty Opportunity: Local Control } \\
\text { of Secondary Schools and Student } \\
\text { Achievement in the Philippines }\end{array}$ & $\begin{array}{l}\text { Marlaine E. Lockheed } \\
\text { Qinghua Zhao }\end{array}$ & January 1992 & $\begin{array}{l}\text { D. Eugene } \\
33678\end{array}$ \\
\hline WPS826 & $\begin{array}{l}\text { Do Workers in the Informal Sector } \\
\text { Benefit from Cuts in the Minimum } \\
\text { Wage? }\end{array}$ & Ariel Fiszbein & January 1992 & $\begin{array}{l}\text { N. Perez } \\
31947\end{array}$ \\
\hline WPSB27 & $\begin{array}{l}\text { Free Trade Agreements with the } \\
\text { United States: What's In It for Latin }\end{array}$ & $\begin{array}{l}\text { Refik Erzan } \\
\text { Alexander Yeats }\end{array}$ & January 1992 & $\begin{array}{l}\text { J. Jacobson } \\
33710\end{array}$ \\
\hline
\end{tabular}


Policy Research Working Paper Series

Title

Author

Date

Contact

Arvil Van Adams

Aflects Human Resource

Robert Goldfarb

January 1992

V. Charles

Development

Terence Kelly

WPS829 Regulation of Securities Markets:

Terry M. Chuppe

January 1992

33651

Some Recent Trends and Their

Michael Atkin

F. Harbottle

Implications for Emerging Markets

WPS830 Fixed Parity of the Exchange Rate and Economic Performance in the CFA Zone: A Comparative Study

WPS831 Real Overvaluation, Terms of Trade Shocks, and the Cosi to Agriculture in Sub-Saharan Africa

Ibrahim Elbadaw

Nader Majs

Ibrahim Elbadawi

Richard B. Norgaard

of Assuring Assets for Future

Generations

WPS833 Stabilization and Growth Recovery

in Mexico: Lessons and Dilemmas

WPS834 Scenarios for Growth in the 1990s

WPS835 Commodity Stabilization Funds

WPS836 Sources of Income Inequality in Rural Pakistan: A Decomposition Analysis

Richard H. Adams, dr. Harold Alderman

Arvil Van Adams John Middleton

Adrian Ziderman
39616

January 1992

V. Barthelmes 39175

January 1992

V. Barthelmes 39175

January 1992

J. Shin Yang

81418

January 1992

L. Franchini 38835

January 1992

J. Queen

33740

January 1992

S. King-Watson 31047

January 1992

C. Spooner 30464

January 1992

S. Khan 33651 